\title{
EKSTRAKSI DAN IDENTIFIKASI SENYAWA ANTOSIANIN DARI JANTUNG PISANG RAJA (Musa $X$ paradisica $L$.) SERTA UJI AKTIVITAS ANTIOKSIDANNYA
}

\author{
Jessica Alvionita, Djaswir Darwis, Mai Efdi \\ Laboratorium Kimia Organik Bahan Alam, Jurusan Kimia FMIPA, Universitas Andalas \\ Email: jessicaalvionita@yahoo.com
}

\begin{abstract}
Anthocyanin compound have been successfully extracted from plantain bud (Musa $\mathrm{x}$ paradisiaca $\mathrm{L}$ ) which can used as natural colorant and antioxidant. Anthocyanin compound was extracted using maceration method with solvent ethanol that has been acidified with acetic acid and citric acid until $\mathrm{pH}$ 1.5. The extract anthocyanin is identified by UV-Vis spectrophotometer $(260-800 \mathrm{~nm})$ and retrieved two peaks that are $277 \mathrm{~nm}$ (UV) and $533 \mathrm{~nm}$ (Visible). Further treatment is carried out with KCKT-DAD at a wavelength $516 \mathrm{~nm}$. Anthocyanin treatment given temperature and $\mathrm{pH}$. Total anthocyanin monomeric obtained for ethanol + acetic acid was $30.22 \mathrm{mg} / \mathrm{L}$; ethanol + citric acid was $18.20 \mathrm{mg} / \mathrm{L}$. The warming influence of the anthocyanin compound lead to degradation of color is highest for ethanol + acetic citric on temperature $100^{\circ} \mathrm{C}$ with percentage degradation of $61.97 \%$. The antioxidant activity of the extract was measured by 1,1- difenil-2-pikrilhidrazil (DPPH) the result showed that the anthocyanin extracts from Plantain bud has antioxidant activity ethanol + acetic citric acid extract is very active as an antioxidant with $\mathrm{IC}_{50}$ values of $3,74 \mathrm{mg} / \mathrm{L}$.
\end{abstract}

Keywords: Musa x paradisiaca L., Anthocyanin, Degradation of Color.

\section{PENDAHULUAN}

Bahan pangan merupakan hal yang sangat penting bagi kehidupan manusia, untuk itu mutu dari suatu bahan pangan tersebut harus menjadi perhatian yang sangat penting. Penentuan mutu bahan pangan pada umumnya sangat bergantung pada beberapa faktor di antaranya cita rasa, warna, tekstur, nilai gizi dan sifat mikrobiologis. Tetapi pada aplikasinya faktor warna lebih menjadi perhatian bahkan kadang-kadang sangat menentukan ${ }^{[1]}$.

Dalam dekade terakhir ini penggunaan pewarna dalam bahan pangan sangat populer. Pewarna yang digunakan terbagi menjadi dua jenis yaitu pewarna alami dan pewarna buatan.Terbatasnya kualitas dan sumber pewarna alami menyebabkan penggunaan pewarna buatan berkembang pesat.
Kebanyakan produsen sering menggunakan zat warna sintetis yang tidak aman dan cenderung memberikan efek yang negatif terhadap kesehatan karena bersifat toksik bahkan karsinogenik. Melihat efek samping dari pewarna buatan pangan yang berbahaya dan didukung gaya hidup back to nature maka masyarakat beralih menggunakan pewarna alami yang aman dikonsumsi ${ }^{[2,3]}$.

Saat ini antosianin telah menjadi sumber yang penting bagi pewarna alami dalam produksi bahan pangan, kosmetik, dan farmasi yang dapat digunakan sebagai pengganti dari penggunaan pewarna buatan. Penelitian lainya juga menunjukkan bahwa antosianin memiliki banyak sifat yang menguntungkan bagi kesehatan seperti aktivitas antioksidan. Hal ini juga menjadi alasan terhadap peningkatan penggunaan 
antosianin dalam produksi bahan pangan saat ini $^{[4]}$.

Antosianin mempunyai kestabilan rendah yang bergantung pada suhu, pH,oksigen, cahaya, konsentrasi dari antosianin, dan zat tambahan lain seperti kopigmen ${ }^{[5]}$. Oleh sebab itu penelitian ini bertujuan untuk mengetahui kestabilan antosianin dari segi $\mathrm{pH}$ dan suhu.

Dalam kajian ini akan dibahas tentang proses ekstraksi, karakterisasi dengan UV-Vis (UVVisibel) dan KCKT-DAD (Kromatografi Cair Kinerja Tinggi). Kestabilan antosianin dengan berbagai variasi $\mathrm{pH}$ dan suhu, serta uji aktivitas antioksidannya dari tanaman (Musa x paradisiaca L). Sampel diperoleh dari Nagari Tabek di Kota Batusangkar. Sehingga diharapkan dapat menjadi tambahan data dalam pengembangan antosianin sebagai zat warna alami.

\section{METODOLOGI PENELITIAN}

\section{Bahan}

Bahan-bahan yang digunakan adalah jantung pisang raja sebagai sampel uji, dan bahan kimia berupa pelarut organik seperti etanol teknis $96 \%\left(\mathrm{C}_{2} \mathrm{H}_{5} \mathrm{OH}\right)$ teknis yang didistilasi, asam sitrat $\left(\mathrm{C}_{6} \mathrm{H}_{8} \mathrm{O}_{7}\right)$, asam asetat $\left(\mathrm{C}_{2} \mathrm{H}_{4} \mathrm{O}_{2}\right)$, buffer $\mathrm{pH} 3$, buffer $\mathrm{pH} 5$, buffer $\mathrm{pH} 7$, buffer $\mathrm{pH}$ 9, buffer $\mathrm{pH} 11,1,1$ difenil-2pikrilhidrazil (DPPH), dan bahan kimia lainnya seperti $\mathrm{NaOH} 1 \%$, kloroform $\left(\mathrm{CHCl}_{3}\right)$, Asam klorida $(\mathrm{HCl})$ pekat, asam sitrat, logam magnesium (Mg), besi (III) klorida $\left(\mathrm{FeCl}_{3}\right)$, anhidrida asetat, $\mathrm{H}_{2} \mathrm{SO}_{4}$ pekat, dan pereaksi Meyer.

\section{Peralatan}

Alat yang digunakan adalah seperangkat alat distilasi, plat tetes, alumunium foil, pipet tetes, penangas air, termometer, spektrofotometer $U V$-Vis, (Thermo Scientific - Evolution 201 UV/Vis Spectrophotometer) KCKT-DAD (UFLC-Shimadzu) serta peralatan gelas yang umum digunakan dalam laboratorium.

\section{Persiapan Sampel}

Sampel yang diperlukan untuk penelitian diperoleh dari Nagari Tabek di Kota
Batusangkar. Bagian yang akan diteliti adalah jantung dari tanaman pisang raja (Musa x paradisiaca L.).

\section{Identifikasi Tanaman}

Identifikasi tanaman sampel dilakukan di Herbarium Universitas Andalas (ANDA) Jurusan Biologi FMIPA Universitas Andalas dengan nomor identifikasi 236/KID/ANDA/VIII/2015 Berdasarkan data diketahui bahwa tanaman yang di identifikasi merupakan famili Musaceae dengan jenis/spesies Musa x paradisiaca L.

\section{Ekstraksi Antosianin}

Antosianin diekstrak dengan metode maserasi yaitu sebanyak 150 gram sampel yang telah dipotong kecil-kecil diekstrak dengan 2 jenis pelarut yaitu etanol + asam sitrat, etanol + asam asetat, air + asam asetat, air + asam sitrat hingga $\mathrm{pH}$ 1,5 masingmasingnya sebanyak $500 \quad \mathrm{~mL}$. Pengekstrakkan dilakukan duplo.

\section{Karakterisasi Antosianin dengan UV-Vis}

Karakterisasi antosianin dilakukan dengan spektrofotometer UV-Vis. Metode ini sekaligus digunakan dalam penentuan kadar total monomer antosianin.

\section{Karakterisasi Antosianin Dengan High Performance Liquid Chromatography- Diode Array Detektor (HPLC-DAD)}

Metode HPLC-DAD yang digunakan berpedoman pada metode Huang, 2012 $2^{[7]}$ dengan sedikit modifikasi. Dimana kolom yang digunakan adalah jenis kolom C-18. Fase gerak yang digunakan berupa larutan $\mathrm{A}$ $=2 \%$ asam format, Larutan $\mathrm{B}=$ asetonitril : Air (1: 1) yang mengandung $2 \%$ asam format. Dengan gradien elusi dari $6-10 \% \mathrm{~B}$ selama $0-4$ menit, $10-25 \%$ B dari $8-12$ menit, lalu dibiarkan isokratik dengan $25 \% \mathrm{~B}$ hingga menit ke 13, 25 - 40\% B dari menit 13 - menit ke 20, 40 - 60\% dari 20 - 35 menit, 60 - 100\% B dari 35 - 40 menit, dan kembali ke 5\% B selama 5 menit, dengan kecepatan alir eluen $1.0 \mathrm{~mL} / \mathrm{min}$. Penginjeksian sampel dilakukan sebanyak $100 \mu$, dan pengukuran dilakukan pada panjang gelombang $516 \mathrm{~nm}$. 


\section{Penentuan Kadar Total Monomer Antosianin Dan Kadar Total Antosianin}

Kadar total monomer antosianin dapat dihitung dengan rumus :

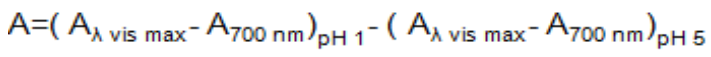

Kadar total Monomer Antosianin $(\mathrm{mg} / \mathrm{L})=\frac{\mathrm{Ax} \mathrm{MW} \mathrm{x} \mathrm{DF} \times 1000}{\varepsilon \times \mathrm{I}}$

Keterangan :

MW : berat molekul sianidin 3-glukosida $(\mathrm{g} / \mathrm{mol})$

DF : faktor pengenceran

$\varepsilon \quad:$ molar absorbsifitas $\left(\mathrm{L} \mathrm{x} \mathrm{mol}^{-1} \mathrm{x} \mathrm{cm}^{-1}\right)$

1 : tebal kuvet $(1 \mathrm{~cm})$

1000: pengubah gram menjadi $\mathrm{mg}$

\section{Perlakuan Terhadap Sampel Variasi pH}

Ekstrak di variasikan pHnya yaitu $\mathrm{pH} 1, \mathrm{pH}$ 3, $\mathrm{pH} 5, \mathrm{pH} 7, \mathrm{pH} 9$ dan $\mathrm{pH}$ 11. Tiap-tiap variasi $\mathrm{pH}$ diukur menggunakan spektrofotometer UV-Vis dengan panjang gelombang $260-800 \mathrm{~nm}$.

\section{Variasi Suhu}

Untuk variasi suhu, sampel di variasikan suhunya yaitu $30^{\circ} \mathrm{C}, 50^{\circ} \mathrm{C}, 70^{\circ} \mathrm{C}, 90^{\circ} \mathrm{C}$, dan $100^{\circ} \mathrm{C}$. Tiap-tiap variasi suhu diukur menggunakan spektrofotometer UV-Vis dengan panjang gelombang $260-780 \mathrm{~nm}$.

\section{Uji Antioksidan}

Pemeriksaan aktivitas antioksidan dilakukan dengan metoda DPPH yang diukur dengan spektrofotometer UV-Vis pada panjang gelombang $515 \mathrm{~nm}$, Aktivitas antioksidan sampel ditentukan oleh besarnya hambatan serapan radikal bebas melalui perhitungan persentase inhibisi serapan 1,1-difenil-2 pikrilhidrazil dengan menggunakan rumus :

$\%$ inhibisi $=\frac{\text { Abs kontrol }- \text { Abs sampel }}{\text { Abs kontrol }} \times 100 \%$

Keterangan :

Absorban kontrol: absorban $3 \mathrm{~mL} \mathrm{DPPH}+2 \mathrm{~mL}$ metanol

Absorban sampel: absorban $3 \mathrm{~mL} \mathrm{DPPH}+2 \mathrm{~mL}$ larutan sampel

Untuk penentuan nilai $\mathrm{IC}_{50}$ (Inhibition Concentration), dilakukan varisasi konsentrasi mulai dari $200 \mu \mathrm{g} / \mathrm{mL}, \quad 400$ $\mu \mathrm{g} / \mathrm{mL}, 600 \mu \mathrm{g} / \mathrm{mL}, 800 \mu \mathrm{g} / \mathrm{mL}$, dan 1000 $\mu \mathrm{g} / \mathrm{mL}$.

\section{HASIL DAN DISKUSI}

\section{Karakterisasi antosianin}

Spektrum yang didapatkan dari pengukuran UV-Vis masing-masing ekstrak memperlihatkan adanya dua puncak serapan yaitu pada daerah UV $277 \mathrm{~nm}$ dan pada daerah Visibel $533 \mathrm{~nm}$. Dugaan sementara antosianin yang terkandung dalam jantung pisang batu adalah antosianin turunan sianidin. Hasil spektrum untuk tiap ekstrak dapat dilihat pada Gambar 1.

Analisa dengan KCKT-DAD didapatkan dua puncak dominan yaitu puncak pada waktu retensi sekitar 13,13 dan 6,88 menit. Sesuai dengan kromatogram standar yang digunakan, jenis antosianin yang terkandung dalam jantung pisang raja adalah sianidin 3galaktosida dan sianidin-3-glukosida untuk kromatogram pada Gambar 2. Untuk kromatogram pada Gambar 3, pada waktu retensi 13,21 menit adanya sianidin 3galaktosida, 11,34 menit untuk sianidin 3glukosida

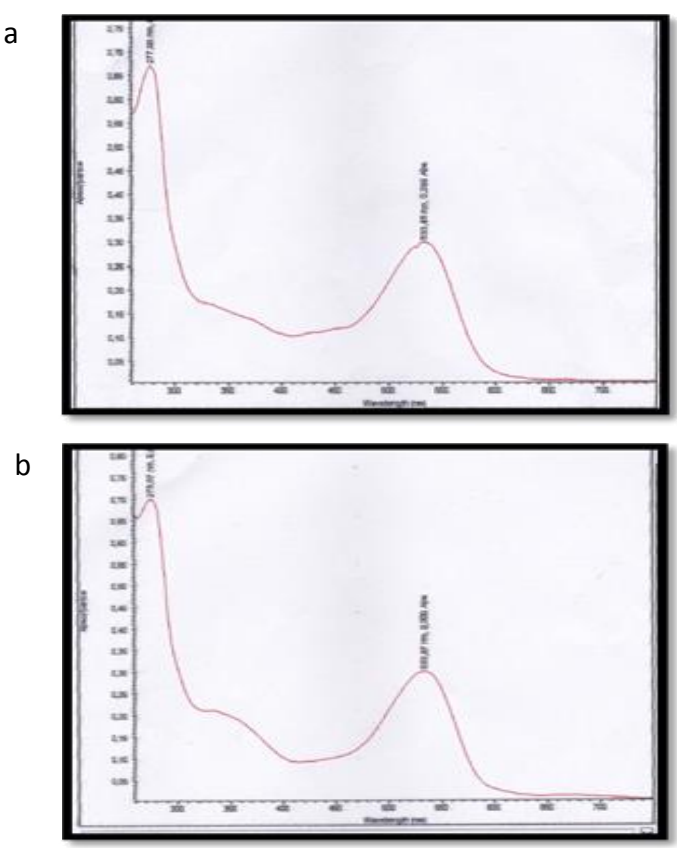

Gambar 1. Spektrum antosianin pada $\mathrm{pH} 1,5$ untuk tiap esktrak : a) etanol + asam asetat, b) etanol + asam sitrat. 
$\mathrm{uV}$

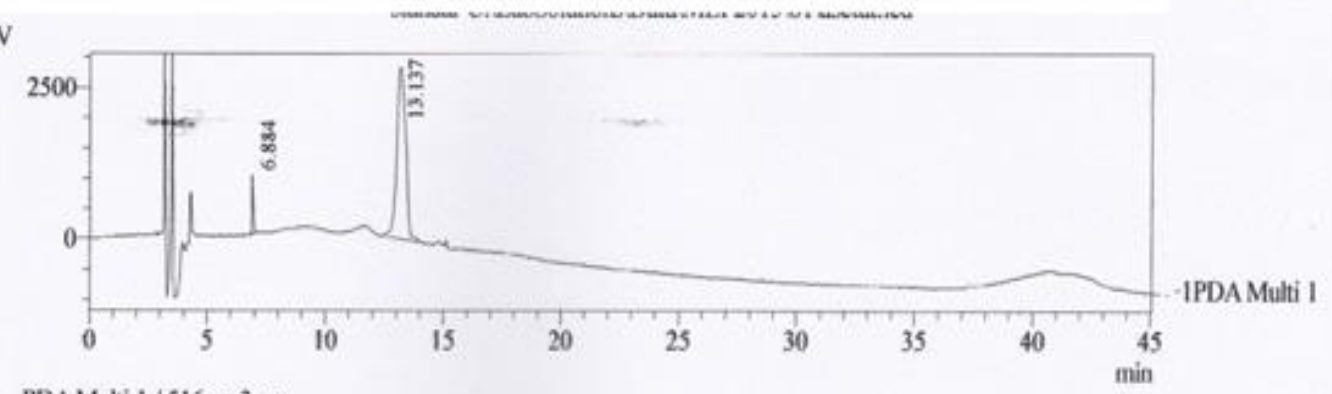

1 PDAMulti $1 / 516 \mathrm{~mm} 3 \mathrm{~mm}$

PDACh1 516nm 3 PeakTable

\begin{tabular}{|r|r|r|r|r|r|}
\hline \multicolumn{1}{|c|}{ PDACaki } & \multicolumn{1}{|c|}{ Ret. Time } & \multicolumn{1}{|c|}{ Area } & \multicolumn{1}{c|}{ Height } & Area \% & \multicolumn{1}{|c|}{ Height \% } \\
\hline 1 & 6.884 & 2818 & 970 & 3.607 & 25.403 \\
\hline 2 & 13.137 & 75321 & 2847 & 96.393 & 74.597 \\
\hline Total & & 78139 & 3817 & 100.000 & 100.000 \\
\hline
\end{tabular}

Gambar 2. Kromatogram ekstrak etanol yang diasamkan dengan asam asetat.

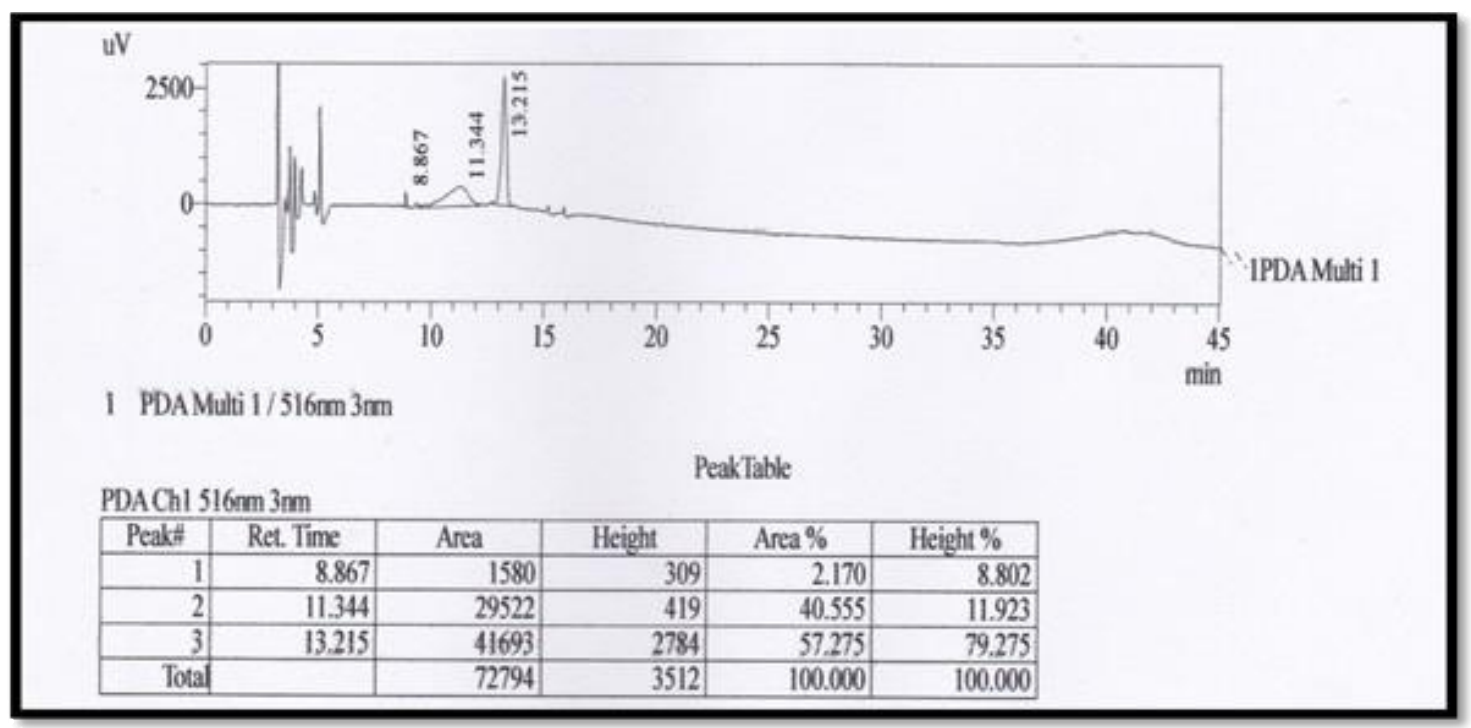

Gambar 3. Kromatogram ekstrak etanol yang di asamkan dengan asam sitrat.

Kadar total monomer antosianin didapatkan dari perhitungan dengan metode $\mathrm{pH}$ differensial adalah sebanyak $30,22 \mathrm{mg} / \mathrm{L}$ pada ekstrak etanol yang diasamkan dengan asetat, $18,20 \mathrm{mg} / \mathrm{L}$ pada etanol yang diasamkan dengan asam sitrat,Hasil ekstrak dapat dilihat pada Gambar 4 dan Gambar 5.

Jika dibandingkan dari segi asam, kandungan antosianin ekstrak dengan asam asetat lebih tinggi dibanding dengan asam asitrat. Jika dilihat dari pKa asam asetat $(4,76)$ yang lebih kecil dibanding $\mathrm{pKa}$ asam sitrat $(6,39)$. Sehingga asam asetat jauh lebih kuat keasamannya yang menyebabkan ekstrak antosianin yang dihasilkan lebih bagus dalam pengekstrakan.

\section{Analisa pengaruh pH dan suhu terhadap kestabilan antosianin}

Semakin asam kondisi larutan $(\mathrm{pH}<7)$, maka warna antosianin akan semakin merah. Sebaliknya, semakin basa kondisi larutan $(\mathrm{pH}>7)$ maka warna merah antosianin akan semakin berkurang (Gambar 6). Hal ini dikarenakan bahwa antosianin mengalami degradasi selang kenaikan $\mathrm{pH}$. 


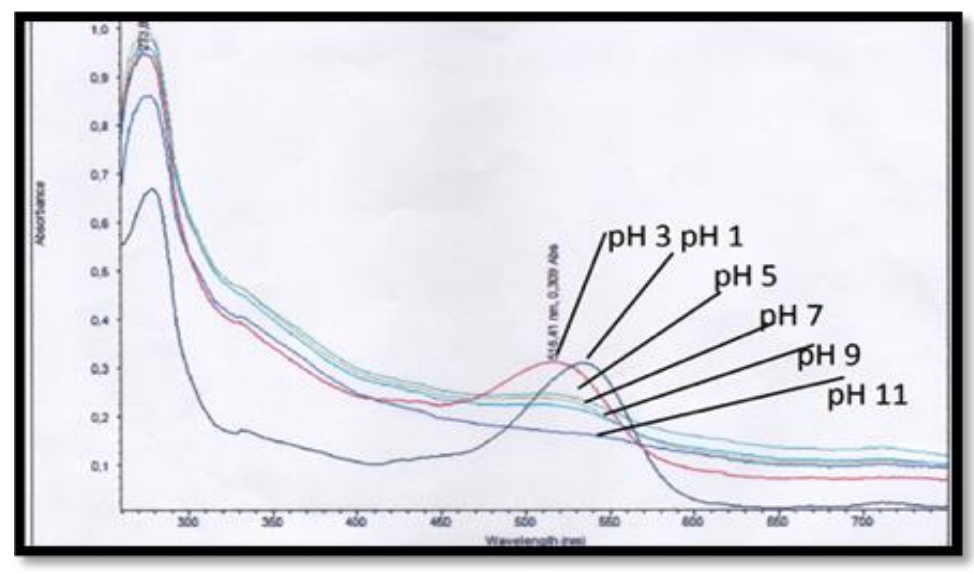

Gambar 4. Perubahan spektrum UV-Vis variasi pH ekstrak etanol yang diasamkan dengan asam asetat.

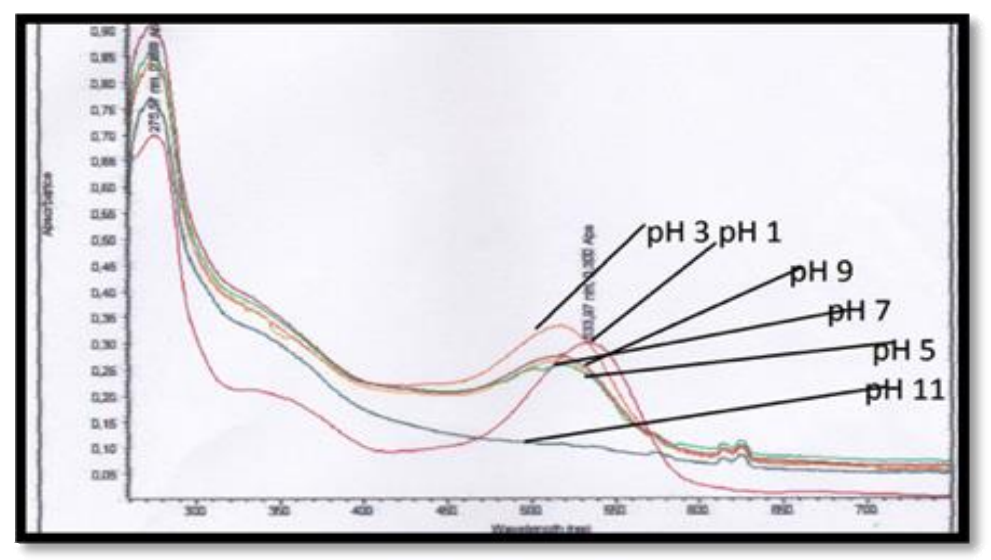

Gambar 5. Perubahan spektrum UV-Vis variasi $\mathrm{pH}$ ekstrak etanol yang diasamkan dengan asam sitrat.

a

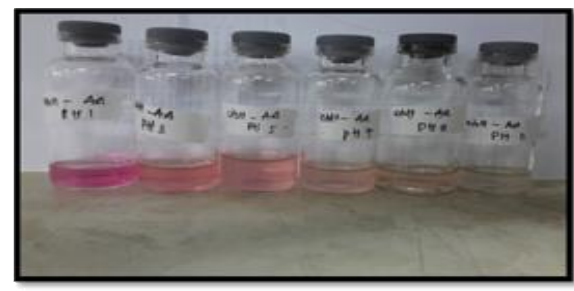

b

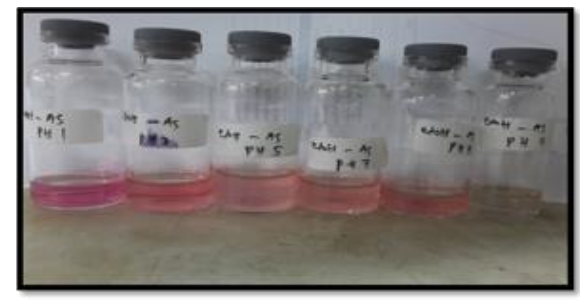

Gambar 6. Hasil ekstraksi jantung pisang raja dengan 2 jenis pelarut a) Etanol + Asam Asetat, b) Etanol + Asam Sitrat.
Berdasarkan data yang diperoleh, dapat dilihat bahwa senyawa antosianin sangat stabil pada $\mathrm{pH} 1$ sampai 3 dikarenakan kation flavilium sangat stabil pada $\mathrm{pH}$ asam. Namun dengan menurunnya derajat keasaman, antosianin berubah struktur. Perubahan warna antosianin dalam tingkatan $\mathrm{pH} 5$ mengarah ke tidak bewarna, hal ini disebabkan membentuk pseudobasa yang mulai kehilangan warna pada rentang $\mathrm{pH} 4-6$, kemudian bentuk pseudobasa ini mengalami tautomerik, keseimbangan antara bentuk keto dan bentuk enol mengahasilkan alfa diketon, dan pH 7 dan pH 9 antosianin akan berubah struktur menjadi suatu basa kuinoidal yang bewarna biru. Seiring dengan kenaikan $\mathrm{pH}$ juga terjadi pergeseran panjang gelombang ke arah hipsokromik. Hal ini terjadi karena adanya penghilangan konjugasi dari struktur antosianin. 
Pada pH 11 antosianin terdegradasi secara keseluruhan sehingga menyebabkan senyawa antosianin tidak stabil yang ditandai dengan penurunan nilai absorban dan warna berubah menjadi tidak bewarna. Perubahan warna ekstrak jantung pisang raja terhadap pengaruh $\mathrm{pH}$ merupakan suatu indikator dari antosianin tersebut, karena dapat berubah warna terhadap faktor keasaman dan kebasaan dari larutannya ${ }^{[7]}$. Perubahan warna antosianin jantung pisang raja terhadap perubahan suhu pemanasan juga memberikan efek penurunan intensitas warna dan absorban pada ekstrak (Gambar 8).

Penurunan absorban seiring dengan kenaikan suhu dapat juga menentukan persentase degradasi antosianin yang menerangkan kemampuan antosianin untuk tetap stabil jika dipanaskan (Gambar 9 dan 10). Dengan nilai persentase degradasi yang paling tinggi ialah $61,97 \%$ pada ekstrak etanol yang diasamkan dengan asam sitrat. Dan data hasil dari perhitungan dapat dilihat pada Tabel 1 .

\section{Analisa Uji Aktivitas Antioksidan Antosianin}

DPPH (2,2-difenil-1-pikrilhidrazil) adalah senyawa yang memiliki radikal pada atom nitrogen. Proses penangkalan radikal bebas oleh ekstrak ditandai dengan memudarnya warna larutan dari ungu menjadi kuning. Dari uji ini dapat ditentukan nilai $\mathrm{IC}_{50}$ masingmasing ekstrak yang diperlihatkan oleh Tabel 2. a

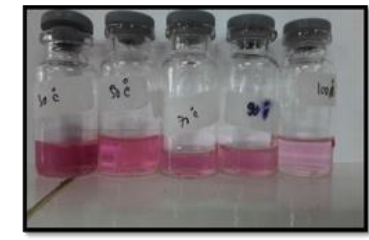

b

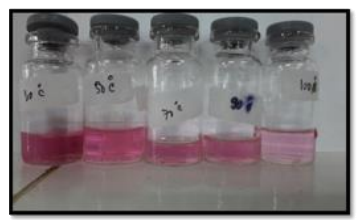

Gambar 8. Pengaruh suhu pemanasan pada ekstrak a) etanol yang diasamkan dengan asam asetat b) ekstrak etanol yang diasamkan dengan asam sitrat terhadap kestabilan antosianin.

Tabel 1. Persentase degradasi warna antosianin akibat pemanasan

\begin{tabular}{ccc}
\hline Jenis Pelarut & $\begin{array}{c}\text { Suhu } \\
\left({ }^{\circ} \mathrm{C}\right)\end{array}$ & $\begin{array}{c}\% \\
\text { Degradasi }\end{array}$ \\
\hline Etanol & 30 & Kontrol \\
+ & 50 & 11,76 \\
asam asetat & 70 & 22,49 \\
& 90 & 28,02 \\
& 100 & 47,40 \\
\hline Etanol & 30 & Kontrol \\
+ & 50 & 17,96 \\
asam sitrat & 70 & 32,03 \\
& 90 & 32,93 \\
& 100 & 61,97 \\
\hline
\end{tabular}

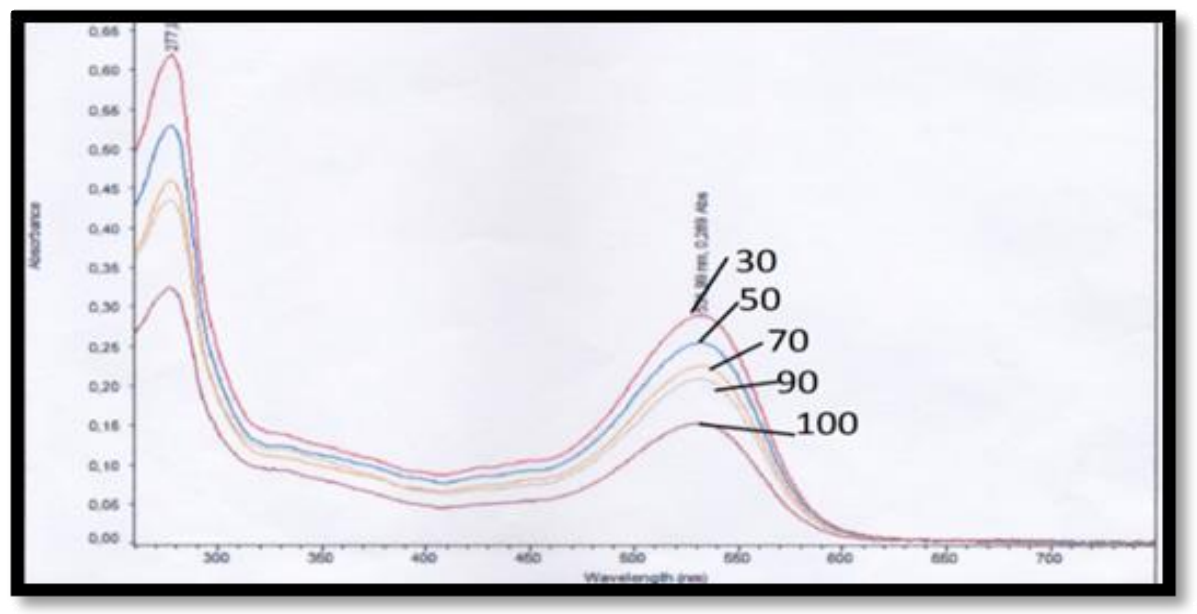

Gambar 9. Perubahan spektrum variasi suhu ekstrak etanol yang diasamkan dengan asam asetat. 


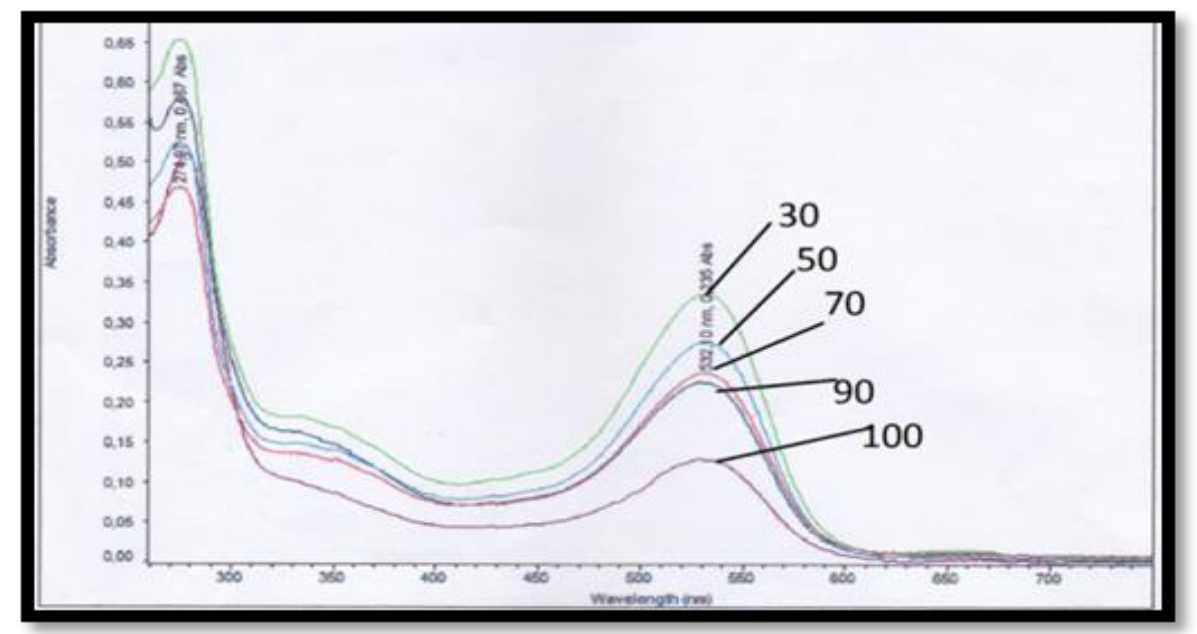

Gambar 10. Perubahan spektrum variasi suhu ekstrak etanol yang diasamkan dengan asam sitrat.

Table 2. Nilai $\mathrm{IC}_{50}$ Ekstrak Antosianin dari Jantung Pisang

\begin{tabular}{lll}
\hline Jenis Pelarut & $\begin{array}{l}\text { Nilai } \\
(\mu \mathrm{g} / \mathrm{mL})\end{array}$ & $\mathrm{IC}_{50}$ \\
\hline $\begin{array}{l}\text { Etanol yang diasamkan } \\
\text { dengan Asam Asetat }\end{array}$ & 5,95 \\
$\begin{array}{l}\text { Etanol yang diasamkan } \\
\text { dengan Asam Sitrat }\end{array}$ & 3,74 &
\end{tabular}

Secara spesifik, suatu senyawa dikatakan antioksidan sangat kuat jika nilai $\mathrm{IC}_{50}$ kurang dari $50 \mu \mathrm{g} / \mathrm{mL}$, kuat jika $\mathrm{IC}_{50}$ bernilai 50 $\mu \mathrm{g} / \mathrm{mL}$ sampai $100 \mu \mathrm{g} / \mathrm{mL}$, sedang jika $\mathrm{IC}_{50}$ bernilai $100 \mu \mathrm{g} / \mathrm{mL}$ sampai $150 \mu \mathrm{g} / \mathrm{mL}$ dan lemah jika $\mathrm{IC}_{50}$ bernilai $151 \mu \mathrm{g} / \mathrm{mL}$ sampai $200 \mu \mathrm{g} / \mathrm{mL}^{8}$

Dari Tabel 2 dapat disimpulkan bahwa antosianin dari jantung batu baik sebagai antioksidan karena memiliki nilai $\mathrm{IC}_{50}$ kurang dari $50 \mu \mathrm{g} / \mathrm{mL}$ terutama pada ekstrak etanol yang diasamkan dengan asam sitrat.

\section{KESIMPULAN}

Jantung pisang raja mengandung antosianin dengan senyawa turunan sianidin yang lebih dominan dengan kadar total monomer pada ekstrak etanol yang diasamkan dengan asam asetat yang paling banyak sebesar 30,22 $\mathrm{mg} / \mathrm{L}$. Antosianin yang diperoleh stabil pada $\mathrm{pH}$ 1- 3 dan tidak terlalu mengalami kerusakan dengan variasi suhu, dengan persentase degradasi tertinggi sebesar 61,97 $\%$ pada ekstrak etanol yang diasamkan dengan asam sitrat pada pemansan suhu $100^{\circ} \mathrm{C}$ dan nilai $\mathrm{IC}_{50}$ dari ekstrak dari ekstrak tersebut sebesar $3,74 \mu \mathrm{g} / \mathrm{mL}$.

\section{UCAPAN TERIMA KASIH}

Terimakasih kepada ibu Mitralena selaku Analis Laboratorium Kimia Organik Bahan Alam Universitas Andalas.

\section{DAFTAR PUSTAKA}

1. Winarno, G., 2004. Kimia Pangan dan Gizi. PT Gramedia, Jakarta.

2. Yoga, Matius Kristiarso, Wibowo Catur. Antosianin Jantung Pisang Kepok (Musa $x$ Paradisiaca) Sebagai Pewarna AgarAgar (Kajian Berdasarkan Stabilitas Terhadap Cahaya Dan Organoleptik). Salatiga.

3. Barnes, Jeremi S., 2010. Analytical Characterization of Anthocyanins from Natural Product by Reverse-Phase Liquid Chromatography-Photoidiode Addar-Electrospray Ionization-Ion of Flight Mass Spewctrometry. Master of Science in Chemistry. The University of Texas at Arlington. 
4. Lestario, Danu dan Kris., 2009. Kandungan Antosianin dan Antosianidin dari Jantung Pisang Klutuk ( Musa brachycarpa Back) dan Pisang Ambon (Musa acuminata Colla). Jurnal Teknologi dan Industry Pangan. Salatiga. Volume XX, No. 2, Hal 143 148.

5. Armour publishing Pte Ltd., 2009., Tress of our garden city. National parks Board. Singapore. Edition $2^{\text {nd. }}$ Hal 184185.

6. Huang, Wen Jian, Shao-Ling Zhang., Gai-Hua Qin,Le Wenqua, Jun Wu., 2012. Isolation and determination of Major Anthocyanin Pigment in The
Pericarp of P. Communis L. Cv. 'Red Du Comices' and Their Associatio with Antioxidant Activity. African Journal of Agricultural Research, Vol. 7 (26),37723780 .

7. Supiyanti, Wiwin, E. D., Dwi Wulansari,dan Lia Kusmita.,2010. Uji Aktivitas Antioksidan dan Penentuan Kandungan Antosianin Total Kulit Buah Manggis (Garcinia Mangostana L). Majalah Obat Tradisional, 15(2), 64 70.

8. Anonim. 2012. Stabilitas Antosianin Buah Duwet (Syzygium cumini) Dalam Minuman Model. Jurnal IPB, Bogor. 